\title{
Trente ans ou la Vie d'un scientifique
}

\author{
Vladimir A. Kitov ${ }^{1}$, Valery V. Shilov ${ }^{2}$, and Sergey A. Silantiev ${ }^{2}$ \\ ${ }^{1}$ Plekhanov Russian University of Economics, Moscow, Russia \\ vladimir.kitov@mail.ru \\ ${ }^{2}$ National Research University Higher School of Economics, Moscow, Russia \\ \{vshilov, ssilantiev\}@hse.ru
}

\begin{abstract}
Anatoly Kitov is one of the outstanding representatives of the first generation of scientists who created Soviet cybernetics, computer engineering and informatics. This paper presents an overview of his more than three decades long attempts to prove to the Soviet leaders the necessity of creation of a nation-wide computer network automated system for the planning and management of the socialist economy. The overview includes a review of Kitov's appeals to the Communist Party leaders Nikita Khrushchev, Leonid Brezhnev, and Mikhail Gorbachev. For the first time Kitov's struggle with the Communist Party and Soviet bureaucracy during perestroika is described and some related documents are published as well.
\end{abstract}

Keywords: Anatoly Kitov, automated management systems, unified state network of computer centers, EGSVTs, OGAS, ASU.

The voice of him that crieth in the wilderness.

Isaiah, 40:3.

\section{Introduction}

The life and works of outstanding Soviet scientist Anatoly Ivanovich Kitov (19202005) are attracting the attention of Russian and foreign historians of science and of writers and filmmakers as well. It is not surprising because his biography is full of great ideas and plans, pioneering works and dramatic episodes. These are the cruel battles in the World War II, the struggle for the recognition of cybernetics in the USSR, the very first monographs on computers and programming in this country, etc.

In just a few years after the appearance of the first brochure about Kitov [1] two books $[12,13]$ and dozens of articles have been published.

Some of them concern his biography $[2,3,8]$, others analyze his organizational activity [11], his struggle for the recognition of cybernetics [14], describe his scientific work in the programming and design of algorithmic languages [4, 9], etc. Indeed, Kitov opened a number of scientific paths in the field of computer science. He was the first in the USSR who wrote textbooks on electronic computers, programming, algorithmic languages and automated management systems (AMSs). 
He developed the fundamentals of AMSs for defense purposes and applied great efforts for the introduction of computers in the military sphere, economy and medicine. His scientific works, monographs and articles, including those written in co-authorship with such prominent scientists as Axel Berg, Alexey Lyapunov and Sergey Sobolev during 1955-1962, have played an important role in the development of cybernetics and computer science in the Soviet Union.

In different periods of the scientist's life various of his works came to the forefront in different fields where computers could be used, such as warfare, economics, health care, program and information retrieval systems. However, the main idea of his entire scientific activity, originated in the late $1950 \mathrm{~s}$, was the vital necessity for USSR to create a nation-wide AMS. Besides technological breakthroughs, Kitov saw also advantages in the application of scientific methods to the management of the country and its economy, and in the transfer of a state power to a generation of comprehensively educated people, not blinkered by communist dogmas. He considered the implementation of this project as a kind of bloodless revolution in which along with the widespread introduction of the most modern computer technologies there would be a natural transfer of power from the state to the people who understood these technologies. He tried to explain the significance of his proposals to sequentially changing Kremlin leaders for three decades. The analysis of Kitov's attempts to establish a dialog with these leaders is the subject of the present paper.

\section{First Proposals}

At the beginning of 1960s the USSR economic complex consisted of hundreds of thousands of enterprises. The expansion of the economy was accompanied by an increase of complication of its management. The demand to achieve a planned balance of economy required the processing of huge amounts of data, and the coordination between all the sectors and spheres of industry. It was obvious that the flow of economic information had become too extensive to manage it manually or with the help of mechanical or electromechanical calculating devices. In the state management there was an urgent need to use computer technologies and automated management systems built on their basis [15].

Kitov was the first who raised the problem of the necessity of a unified management system for the national economy and military-industrial complex in the USSR based on computer technologies [5, 17]. Kitov stated for the first time his ideas concerning the restructuring of economy management of the Soviet Union by building a countrywide computerized management system based on a unified state network of computer centers in the 1958 brochure "Electronic computing machines" 1

At the end of the 1950s, while being the Deputy Chief of Science in Computing Center No. 1 of the Ministry of Defence, he developed the project of computers application for the management of Soviet economy, reducing the influence of

${ }^{1}$ Kitov, A.I.: Electronic computing machines (Электронные вычислительные машины). Znanie, Moscow (1958). 
subjective factors in decision-making and greatly increasing the efficiency of industrial and transport enterprises. Technically he considered AMSs as a network of thousands of computer centers covering the entire territory of the USSR.

In January 1959 Kitov sent to the First Secretary of the Communist party of the Soviet Union (CPSU) Central Committee and Chairman of the USSR Council of Ministers Nikita Khrushchev a letter in which he proposed to change radically the methods and means of the Soviet Union economy management by the "transition from manual and individual forms of management to automated systems based on the use of computers" [6].

This document is of great interest for historians ${ }^{2}$. After the obligatory ritual addressing to the head of state, the author immediately moves to the essence of his proposals. Namely, to the fact that there was a "vitally important necessity" in the restructuring of the national economy and the creation of a nation-wide AMS. Those measures undertaken at that time, such as the "reorganization of management in industry according to a territorial principle", in the opinion of the author, although "have led to an improvement of the situation", did not eliminate the shortcomings in the work of the executive governmental bodies at all levels. In particular, he writes that systematic measures carried out to reduce administrative staff did not give the expected results, because they were implemented by using old methods and means of management. Kitov offered to put in the base of automated system application of scientific methods (methods of mathematics, rather than Marxist-Leninist philosophy and political economy: it is necessary "to move from general discussions about the advantages of socialism to solving the real problems raised by life") and computers. He concluded that the situation could be improved everywhere, all over the country, by using computers. In other words, Kitov suggested moving from the subjective and voluntaristic style of management to AMSs. He stressed that this would allow using in full such features of socialist system as the planning all over the country and the principle of centralized management. The introduction of AMSs will allow to make a real impact not only "on words", significantly reducing the extremely extended bureaucracy of the country.

Kitov proposed to build the AMS gradually: at the first stage electronic computers were to be installed in economic councils, ministries, departments, and the largest enterprises as well. Then the separate computers were supposed to be connected by the "automatic communication lines in more or less large complexes". Then these complexes (computing centers) should be integrated to the nation-wide AMS. Later on, Kitov named it EGSVTs ${ }^{3}$.

An important thesis of his letter is that all efforts are doomed to failure because of the reaction of opposing forces whose interests would be imminently infringed by the wide automation of management processes. To avoid this, a "special, very

${ }^{2}$ Kitov's letter to the First Secretary of the CPSU Central Committee and Chairman of the USSR Council of Ministers Nikita Khrushchev from January 7, 1959 is published in A Appendix. The document is published according to the signed and dated author's copy handed by his family to the Polytechnical Museum of the Russian Federation (f. 228, d. КП27189/20).

3 EGSVTs (ЕГСВЦ) - Russian abbreviation for "Edinaya Gosudarstvennaya Set' Vychislitel'nykh Tsentrov" (Unified State Network of Computer Centers). 
authoritative" state body (no less than of a state ministry level) responsible for the introduction of AMSs in the country should be established. This body had to "be able to carry out control and analysis of the work of various administrations, central state boards, committees, individual institutions and enterprises, to develop projects for automation and reorganization of their activity, providing the mandatory implementation of the planned measures".

Leonid Brezhnev, at that time the Secretary and Member of the Presidium of the CPSU Central Committee, considered Kitov's letter to Khrushchev. He asked Kitov to clarify the essence of his proposals. Later on, in conversation with Professor Pavel Muzychkin, Kitov recalled this visit:

"They summoned me to the Central Committee. At that time these issues (science and technology, ndr) were supervised by Leonid Brezhnev. By then he was a rather progressive person. He told me: 'Here you are offering this and that. But we use a rather different approach. If there is any problem, we organize meetings with Soviet proletarians and kolkhozniks. We discuss with them. After that we make decisions'. And you know, Pavel Arsenovich (Muzychkin, ndr), I answered him plainly:

'Leonid Il'ich, if you get sick, would you also call for the workers and kolkhozniks to consult or listen specialists who know how to treat the disease?'” [12, p. 265-266].

Kitov's letter was written on the eve of XXI (extraordinary) Congress of the CPSU, held from January 27 to February 5, of the same 1959. We believe that the letter had a significant influence on science and technology policy of the USSR in the field of computer technologies, although the resolutions of this congress did not show directly this fact. Referring to Congress approved "control figures of the national economy development in $1959-1965 " 4$, it is easy to see that they are mainly quantitative indicators, talking about the implementation of the "historic task - to catch up and overtake the most developed capitalist countries in the production sphere" 5 . It was not noted the emergence of a fundamentally new phenomenon computers. For example, computers are only mentioned in the section devoted to the successes of Soviet science and technology: a short list of the achievements in nuclear industry (the first in the world nuclear power electric station, nuclear-powered icebreaker "Lenin" and the world's most powerful particle accelerator), "serial production of intercontinental ballistic missiles", first artificial Earth satellite and at the very end of the document is noted that "a number of high-speed electronic machines have been designed" 6 . However, these machines were supposed to be used only for production purposes: "Wide prospects in the automation of production processes are opened by the achievements of computing technology. The application of modern computers for industrial processes allows selecting and maintaining automatically the most optimal technological process"7.

The possibility of the application of computers for other purposes was not even mentioned. Moreover, computers were not in the priority list of engineering products

\footnotetext{
${ }^{4}$ XXI Congress launched the first (and the last) "seven-year country development plan" in the history of the USSR.

${ }^{5}$ Extraordinary XXI Congress of the Communist Party of the Soviet Union. Verbatim report, vol. 2, p. 456. Politizdat, Moscow (1959).

${ }^{6}$ Ibid., p. 468.

${ }^{7}$ Ibid., p. 487.
} 
planned to be increased significantly (for the state of the Soviet computer industry in 1948-1960 we refer to $[10,19])$.

However, as recalled by Vladimir Isaev, one of the Kitov's colleagues, after the Congress a special government commission chaired by the famous Soviet scientist and radio technician Admiral and Academician Axel Berg was organized according to a joint decree of the CPSU Central Committee and the USSR Council of Ministers for considering Kitov's letter. The Commission endorsed all the initiatives of the Deputy Head of the Computing Center No. 1 of the Ministry of Defence, colonel Kitov ${ }^{8}$. In June 1959 an All-Union Conference was held, which proclaimed a policy of "accelerated development and application of computers and the widest possible introduction of automation and mechanization in the industrial production in the USSR" [12, p. 144].

In the late June of the same year the Plenum of the CPSU Central Committee considered the problems of accelerating the technological progress in the industry. The following Resolution was adopted:

"Taking into consideration the great potential of electronic technology in the field of automation of industrial processes the USSR State Planning Committee, the State Committee on automation and machine building of the USSR Council of Ministers along with participation of the State Committee on radio-electronics of the USSR Council of Ministers and in coordination with the Soviet Republics are charged with the development of a plan for the introduction of radio-electronic technologies in all the sectors of the national economy" .

We may assume that Kitov's letter became some kind of a catalyst for the adoption of such important decisions on the development and introduction of computers. However, it should be noted that Kitov's main proposal to establish a countrywide AMS for economy on the basis of a nation-wide network of computer centers was not supported by the leadership of the Soviet Union. It seems appropriate here to quote Professor Ivan Pogozhev:

"From all of the character traits of Anatoly Kitov I would like to distinguish in particular:

- The ability to see first the new progressive directions in science and give to it all his power immediately, despite the troubles that it could have brought to him personally $<\ldots>$

- His total lack of veneration and fear of higher authorities. He always told the truth, in which he was convinced, to the authorities just as definitely and frankly, as to any of his friends" [12, p. 309].

Exactly these traits noted by memoirist suggested Anatoly Kitov to take a second attempt to "reach out" to the country's top leadership. In the autumn of 1959 he sent a second letter to Nikita Khrushchev, which brought him the most serious negative consequences. The first part of the letter contained a strong criticism of a number of executives and in turn of the leadership of the Ministry of Defence for being slow in the development and introduction of computers in practical work. The main part of

${ }^{8}$ The Minutes of Commission Proceedings have not been yet investigated by specialists, yet they could also be a very valuable historical source.

9 Plenum of the CPSU Central Committee. June 24-29, 1959. Verbatim report, p. 508. Politizdat, Moscow (1959). 
the letter contained a detailed description of Kitov's project "Measures to overcome the shortcomings in the development, production and introduction of computers in the Armed Forces and national economy". Today this project is known among the specialists as the "Red Book" project. It was the first project in the USSR, which proposed to combine all the computers in the country into a unified state network of computer centers. In peacetime this network must have fulfilled both national economic and defense tasks, and in the state of martial law or the threat of war it must have switched totally to defense. Kitov characterized this nationwide computer network as network of "dual-use" or "dual-purpose": for the national economy and Armed Forces [1, p. 8].

However, the bold and innovative proposals of the scientist were not understood in the USSR highest echelons of power. Moreover, when CPSU Central Committee sent the second Kitov's letter to Khrushchev and his "Red Book" project for consideration to the USSR Ministry of Defence, it strongly criticized it. Thus, the CPSU Central Committee in fact directly initiated reprisals against the author of the progressive project on optimization of the country economy and army management. As Kitov recalled:

"The report I presented before the commission, headed by Marshal Konstantin Rokossovsky, contained a serious criticism of the situation concerning the use of computers, especially in the Ministry of Defence. This caused a negative reaction among the two dozens of listeners - mainly generals. They strongly opposed it: 'The army will not fulfill economic tasks!' As a result, the commission rejected my proposals, called them irrational, because according to their opinion it was not allowed to mix military and civilian tasks. In fact, the people from the power structures did not agree with me because many of them would have lost their high state positions due the widespread introducing of computer technologies. I was expelled from the Communist Party and dismissed from the post of Deputy Head of the Computing Centre No. 1, which I occupied since 1954" [14].

During the discussion of Kitov's proposals at the beginning of 1960 the witness and participant of those events Konstantin Kurbakov recalls that “... very negative voices of Communist Party functionaries and government officials sounded on all meetings: 'And who are those who will decide for us?', 'And where is the leading role of the Communist Party?' etc. ... I remember what an unpleasant discussion was at the meeting in the State Committee on Science and Technology. Immediately after Kitov's report officials put forward the accusation that Kitov "proposed a substitution of centralized Communist Party economic state institutions in the country by computer based system of independent 'local barons"' [12, p. 236].

After some time, Kitov was also dismissed from the Soviet Army.

\section{Two Decades of Miscommunication}

Nevertheless, in spite of the reprisals Kitov continued his scientific activity. He spoke at various meetings and conferences (Fig. 1), published papers, and defended the idea of establishing a nation-wide AMS for the country's economy. 
As stated in [6], "the Director of the Institute of Cybernetics of the Ukraine Academy of Science Victor M. Glushkov (1923-1982) picked up the original idea of Anatoly Kitov and did not let it die". Publications and proposals of Kitov on automation and management of the country's economy through the creation of EGSVTs attracted Glushkov's attention to this subject. Under their influence Glushkov radically changed the direction of his research work from mathematics to cybernetics and computer science. It is almost unknown that Kitov was a close friend of Glushkov and seriously affected his scientific activity. Glushkov creatively reinterpreted and re-worked the ideas and proposals of the "Red Book". In 1962 with the assistance of the President of the USSR Academy of Science Mstislav Keldysh he drew attention of First Deputy Chairman of the USSR Council of Ministers Aleksey Kosygin to the ideas of AMS.

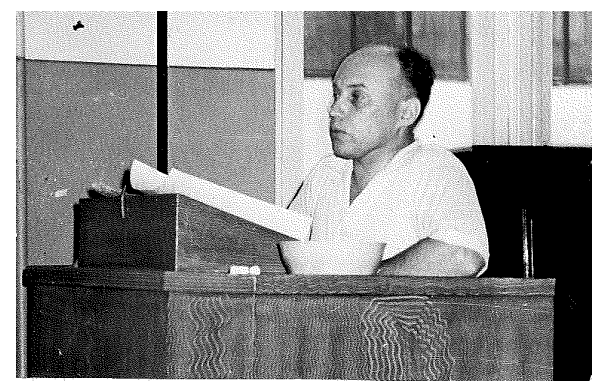

Fig. 1. Anatoly Kitov (scientific conference at Tashkent, 1963). Reproduced by permission from Kitov family papers

In 1960-80s a large-scale campaign for introducing AMS at the level of separate enterprises, institutions and agencies was launched in the country ( $\left.\mathrm{ASU}^{10}\right)$. It seized hundreds of thousands of Soviet citizens and continued till the beginning of "perestroika". Anatoly Kitov in 1960s was Glushkov's deputy on the work carried out in the field of AMSs for the branches of industry (OASU). In 1964, a group of scientists and specialists including Kitov and led by Glushkov proposed a draft of the EGSVTs project. It was not adopted because of many long-term approvals. Somewhere in 1970s, the title EGSVTs was changed to OGAS ${ }^{11}$, but this did not help to accelerate the work... Soviet leadership supported OGAS only on words, not taking any serious actions ${ }^{12}$. In the national press and in the resolutions of various scientific boards and commissions a lot of words were said about the great significance of OGAS, but as the saying is - "Things haven't moved an inch".

At the same time many science officials were employed by OGAS and regularly received various benefits in the form of high-level positions, apartments, cars, etc.

10 ASU (ACY) - is Russian abbreviation for "Avtomatizirovannaya Sistema Upravleniya" (AMS).

${ }^{11}$ OGAS (ОГАC) - is Russian abbreviation for "Statewide Automated Management System for Collection and Processing of Information for the Accounting, Planning, and Management of the National Economy".

${ }^{12}$ About the background and history of the project see for example [15]. 
while the proposals on OGAS were endlessly discussed and coordinated by different public authorities, especially by the USSR State Planning Committee and the USSR Central Statistic Department (both of them had the status of State Ministry). Rewriting paper versions of the OGAS draft was ended only in the early 1980s. But even then this document has not been signed by the project scientific supervisor Glushkov, and it was not approved by other eligible state authorities as well. Thus, the OGAS project remained only on paper, "drowned" in the cycle of long-term interagency coordination due to the failure of USSR leadership to take the concrete decisions. Only a small part of Kitov's and Glushkov's proposals were realized.

Despite the dramatic result of his first appeals to the leadership of the country, Anatoly Kitov did not cease the attempts to "reach out" to the first persons of the Party and State over the next twenty-five years. He was well aware of Soviet society features and clearly realized that in the USSR, with its highly centralized system of state management, only the decisions and actions of higher officials might lead to a systematic and widespread introduction of AMSs and economic-mathematical methods. Between the late 1960s and early 1980s, Kitov addressed several letters to the leader of the country Leonid Brezhnev and some governmental instances. These letters contained constructive suggestions for improving the situation and detailed analysis of the current disappointing state of matter in the country with respect to computers, software, peripherals, communication equipment, and automation in general. However, his proposals were either not understood or did not reach the high level leaders. These documents are still awaiting investigation by science historians.

Kitov was concerned that separate ASU were created in large numbers but without coordination, without a unified state-wide planning and a permanent strong control over their development and implementation, and with enormous expenses of state funds and resources. The process depended upon the degree of desire (or unwillingness!) of various local bosses. Therefore, it is not surprising that the total effect of their application was insignificant. Of course, such an approach did not give the desired results. This, in turn, led to dissatisfaction and disappointment both at the highest and middle management levels.

In the mid-1980s Kitov again tried to attract the attention of the new leadership to the OGAS project. Being at that time the Head of the Department of Computer Engineering in the Moscow Institute of National Economy named after Georgy Plekhanov, he wrote in October 1985 a letter to the General Secretary of the CPSU Central Committee Mikhail Gorbachev [7]. In this message he actually summed up his almost thirty years of efforts for the introduction of computer technologies and AMSs in the USSR. He expressed his concern about the fate of the project and pointed out that in the 1960-70s the development of separate AMSs went on spontaneously in various enterprises, industrial branches and departments. Those developments were scattered, with no effective coordination between the ministries.

This letter focused on two key theses. First, as it was mentioned earlier in the letter to Khrushchev, it was the necessity to establish the All-Union government body (Kitov named it "Goskomupr"13) responsible for the realization of the program and control of all ministries, departments and enterprises in the field of ASU development and introduction. The second one was the necessity to subordinate that body directly

\footnotetext{
${ }^{13}$ Gosudarstvennyi komitet po upravleniyu (State Committee for Management).
} 
to the Politburo of CPSU Central Committee, because this project could have been realized only with the continuous support of the top political leadership. Colleagues and members of the family of the scientist remembered that Kitov was convinced that the establishing of "Goskomupr" would be a sign that the top management of the USSR "not in words but in deeds" supported OGAS project. Only the existence of this body would have allowed the fulfillment of the work according to the coordinated centralized plans. During the disputes with the closest colleagues, he said firmly: "Without establishing of All-Union Ministry for ASU that reports directly to the Politburo the introduction of OGAS is impossible"14.

Apparently, it was simply unrealistic to carry out in any other way such a significant large-scale state-wide project in the framework of the socialist system. This is confirmed by the memoirs of the Academician Boris Chertok (one of the Deputies of the Chief Designer of Soviet space systems Sergey Korolev): "The system of mobilizing the economy was preserved since the Second World War. All plans must have been fulfilled certainly. Failure would have been punished severely. By inertia this style of work continued into the period of "cold war"... The active participation of the government and the coordinated work of high-ranking officials, scientists and developers was needed... It was provided by the Military-Industrial Commission, which was established under the authority of the USSR Council of Ministers and, in fact, top Party leadership. This Commission helped to solve many scientific and technological problems aroused during the implementation of the largescale projects" 15 .

In fact, Kitov suggested to solve the problem of the development of the economy AMS in the USSR as it had been done in case of nuclear weapon and space projects. Kitov's proposals to build an AMS and replace the stagnant Soviet bureaucracy by forcible bureaucratic methods, at first glance, are contradictory. However, here we see his clear understanding of the mechanisms of the Soviet system. Indeed, the abovementioned nuclear weapon and space projects are rare examples of successful solutions of complex scientific and engineering problems in the Soviet Union. The whole experience of Kitov convinced him that only the military (Ministry of Defence, or KGB), or a civilian agency operating under military-like discipline, could realize such ambitious nationwide project. Of course, neither in 1960 nor later the Goskomupr was established by the communist leaders. Already after the second Kitov's letter to Khrushchev they were aware that introducing a AMS in the USSR economy controlled by Goskomupr was a deathly threat to the Party hierarchy. The establishing of Goskomupr actually would have meant the organization of a countrywide structure, replacing significantly Party organs at all levels of power. Taking into consideration the absence of a purely economic stimulus, which could have forced enterprises and agencies to introduce ASU, it seems that the whole idea of automation of economy management was doomed from the very beginning.

${ }^{14}$ Kitov's letter to the General Secretary of the CPSU Central Committee Mikhail Gorbachev from October 9, 1985 is presented in B Appendix. The document is published according to the signed and dated author's copy storing at the Polytechnic Museum of the Russian Federation (f. 228, d. КП 31862/1-2). We do not publish the Appendices to this letter.

${ }^{15}$ Chertok, B.E.: Korolev entered the history of mankind. Russian space (Российский космос), $1,12-15$ (2007). 
There is a handwritten note made by Kitov in November 11, 1985 (Fig. 2). It says that the instructor of Economic Department of the CPSU Central Committee Yury Samokhin called Kitov and informed him that his letter had been considered. Samokhin was authorized to answer the following: "Firstly, thank you for the help in such an important matter. Secondly, not all points of the letter are approved by the Economic Department. The Politburo of the CPSU Central Committee has many other tasks, beside the automation of the national economy management. There is a program on computing engineering adopted by Politburo in January 1985 and this is now the main document. The establishment of the State Committee on Computer Engineering is delayed". Anatoly Kitov asked to answer him in writing, not by telephone. But his request was rejected.
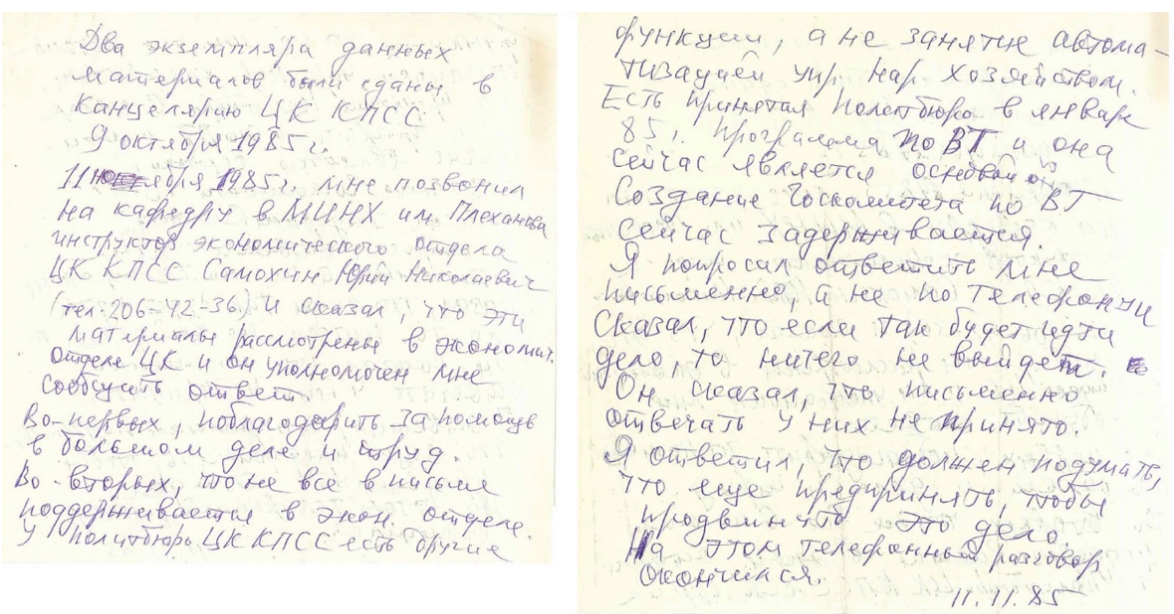

Fig. 2. Kitov's handwritten note, dated November 11, 1985. Reproduced by permission from Kitov family papers

OGAS project finally sank into oblivion during "perestroika". From 1987 to 1989 some laws were adopted, which provided the extension of enterprises autonomy. The main condition for the successful realization of the OGAS project - a rigidly centralized system of economy management - disappeared. On the other hand, OGAS project was already outdated by that time. The emergence and mass distribution in the West of personal computers required a revision of the basic principles of automated systems organization. This meant additional investments, which the Soviet government could not afford due to the growth of serious economic problems. The crisis of the late 1980s significantly reduced the financial capabilities of the Soviet government to fulfill an expensive project of management automation. All these factors buried one of the most ambitious and promising scientific and technological projects of the Soviet era. 


\section{Last Warnings}

However, the elderly scientist did not pile weapons and stop his attempts to express his views on the problem of economy management [16]. In 1987 he sent a long paper to the leading Soviet ideological journal "Communist", but it was rejected. The editor of the science and education section A. Antipov informed Kitov that they "do not consider it appropriate to publish" his article, because the editorial portfolio had already contained "a serial of materials relating to the problems of society informatization". Three years later, Kitov proposed to the same journal another article. The consultant of journal economic section N. Golovnin answered to Anatoly Kitov that his "material" under the title "The problem of the cardinal improvement of the national economy management in the political economy of socialism" was considered and rejected. Golovnin recommended to send the article to the special economic editions because in "Communist" "a limited attention is given to economic problems" (Fig. 3). This argument today produces a very strong impression, because the collapse of the socialist economy was the catalyst for the death of the whole Soviet political system...

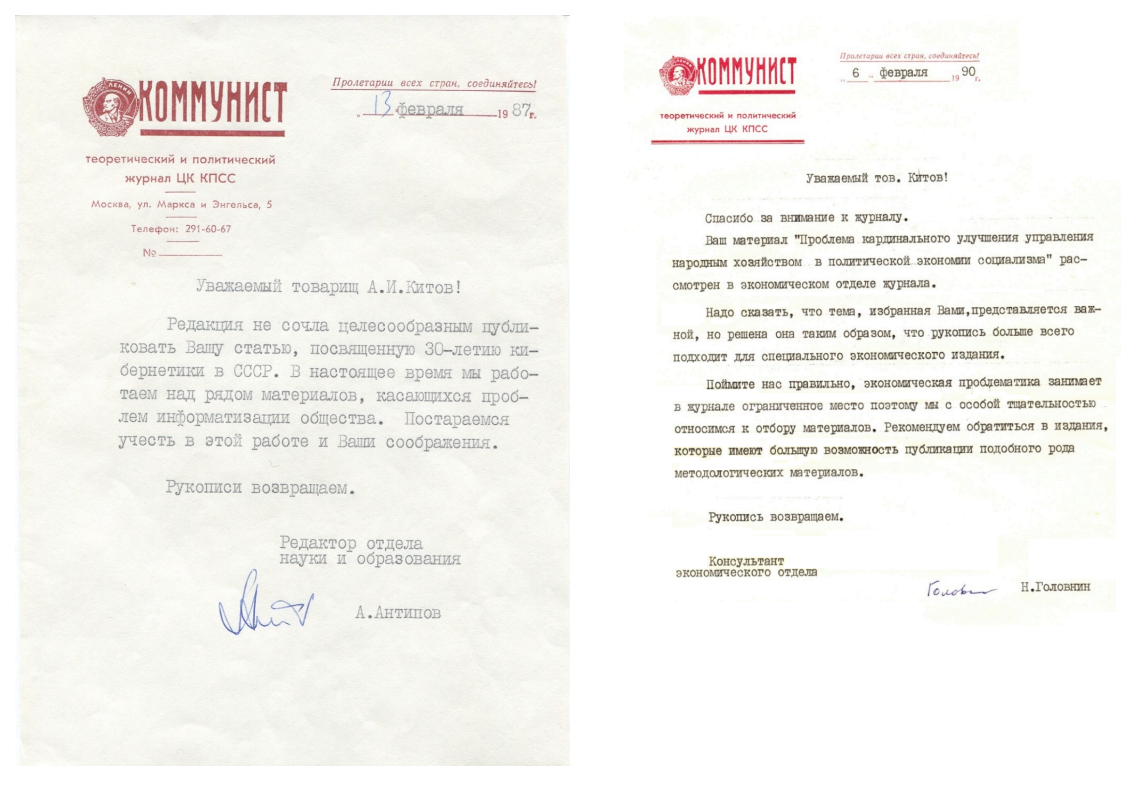

Fig. 3. Letters from "Communist" journal. Reproduced by permission from Kitov family papers

Unable to present his ideas in influential ideological venues, Kitov tried to explain them to the public. The last known Kitov's attempt to openly express his views was undertaken at the scientific conference in Penza in October 1989. He was a Chairman of this conference and many well-known Soviet scientists took part in it. The conference lasted two days and adopted a Resolution (it is presented in excerpts in Appendix C). The document strongly criticized the state of Soviet economy and 
predicted its imminent crash if appropriate measures would not have been undertaken. Among others measures, the introduction of mathematical methods and information systems were suggested. The Resolution contained many other interesting points. For example, it was outlined very clearly and firmly the ineffectiveness of some hastily established governmental (the State Committee on Computer Engineering and Informatics) and (pseudo-)public institutions (the Institute for System Researches and other institutions of the Academy of Sciences), parasitizing on the fashionable computer topic. In this document we see the recognition of the principle of centralized management and planning on a national scale as a fundamental one, but many sound ideas were also expressed. For example, the need of cooperating with the Western countries in the production of computers.

Of course, in the situation of economic collapse and growing political crisis of the Soviet Union this modest document had no practical consequences. Nevertheless, it remains a valuable evidence that not all the scientific community was in captivity of communist ideological demagoguery. Many specialists saw the real state of economy and science, and they tried to deliver their opinions to the governing authorities by all available means. Ignoring of the views of qualified professionals and the blind faith in the magical power of political spells contributed in a large extent to "the failure of senseless plans and worsening of crisis in the country", as was stated in the conference Resolution.

Apparently, Kitov's report "The role of modern computers in improving the management of enterprises and promoting the human factor" presented at the conference was the last speech on the main topic of his scientific activity.

\section{Conclusion}

Unfortunately, Kitov's thirty years attempts to establish a dialogue with the Soviet authorities failed. But the dialogue did not take place - it was only a monologue. Undoubtedly, it was caused by some features inherent to Soviet political system, which determined the relations between state and science (see for example $[18,19]$ ).

In the opinion of Professor Gennady Meshcheryakov, "[...] one of the main reasons of the crisis of the USSR was the fact that the whole system [...] suppressed outstanding innovators such as Anatoly Kitov, who was sincerely concerned about the welfare of his country" [8].

\section{A Appendix}

\section{DEAR NIKITA SERGEEVICH!}

Heartily approving your reforms, I would like to report you, in connection with the 21 Congress of the CPSU, the following considerations related to the prospects of the development of our country. 
At the present time, there is a vital need for a computerized system of administrative and economic management of the country through the application of scientific methods of management organization and electronic computers. $<\ldots>$

The reorganization of the management in industry and civil engineering by a territorial principle has, of course, led to an improvment of the situation. But there are still serious shortcomings in the current and long-term planning, accounting, logistics, coordination of activity of separate enterprises and branches of industry as a whole, personnel training and distribution, effective use of finance, introduction of new technologies and so on. Ongoing systematic measures to reduce the administrative staff do not give the expected results, because they are realized by old means and leadership methods. These reductions are fictitious in their significance, because either vacancies are reduced or the fired staff immediately gets a similar job in other places. In addition, the financial sums saved on administrative personnel reductions are very small in comparison with the huge sums that our country loses annually due to shortcomings in the administrative management. The lack of accurate accounting, planning and control contributes to bureaucratism, irresponsibility and misuses.

The modern level of the development of the productive forces and the complexity and interdependence of the various branches of the national economy requires a radical change and improvement in the management methods by the transition from manual and personal forms of management to automated systems based on the use of computers.

It is very important to give the appropriate attention to this problem in the Report to the 21 Congress of CPSU. Besides the further increasing of industrial production, one of the main tasks of the future seven-year plan must be the automation of administrative and economic management with the help of computers. On this way the most important advantages of the socialist system - planned economy and centralization of management - could be used in full. The creation of an automated management system in our country will be a revolutionary leap in its development and will provide the complete victory of socialism over capitalism.

Automation of management processes will require a large scientific, technical and organizational work in two main directions:

1. The development of scientific methods and forms of management organization at various levels. Economists involved in this work must move from general discussions about the advantages of socialism to the solving of real life problems;

2. The evelopment and introduction of computers and other technical means of automation.

Naturally, the development of an automated national management system should be carried out gradually in several stages. The first step should be the introduction of electronic machines in some of the largest enterprises, departments, committees, and ministries.

Later, these separate machines will be linked together by automatic communication lines in more or less large complexes and in future thet may be combined into a unified automated management system.

Already at the very first stage the introduction of machines should lead to a significant increase in management efficiency and a very significant reduction of administrative staff. However, it is clear that the reduction or elimination of any of 
management agencies can be made only after a complete introduction of the relevant electronic system in the reliable service.

Taking into account the political and economic importance of management automation in the country, the significant workload and that the introduction of computer machinery and, associated with this fact, staff reduction will be met with some resistance, it is needed to establish a special and very authorive body to carry out the work on a national scale. If we let things go without control and provide interested institutions the possibility to decide whether or not to automate their work, then our efforts will be doomed to failure. This body must control and analyze various administrative bodies, committees, individual institutions, and enterprises, must develop projects for the automation and reorganization of their work and must ensure the mandatory implementation of the planned measures.

The existence of such a special state body responsible for the correct scientific organization and automation of management processes will bring uniformity in the structure and activity of various departments and agencies, will allow widespread utilization of scientific and technological achievements and will give an immediate real economic effect.

The task of this body should include the organization of a relevant computer center network in the country and the control of its work. This is the most necessary because the large scale production of machines has been already planned, but preparations for their application still have not been provided. [...]

APPENDIX: Brochure "Electronic computing machines"

With great respect

"7" January, 1959

\author{
A. KITOV \\ Engineer-Colonel, Candidate of technical \\ sciences, Deputy Head for Research of \\ Computing Center No. 1 of the Ministry \\ of Defence.
}

\title{
B Appendix
}

\section{DEAR MIKHAIL SERGEEVICH!}

Let me present you my thoughts on the analysis of the introduction of computers in the economy of our country for the last 30 years.

The purpose of presenting these materials is:

a. To show that this is already the third time that an attempt to solve the problem of automation of the Soviet economy management on the basis of computers is presented, with about the same goals and objectives. The approach still remains the same, and, as before, there will be no progress if we do not change our attitude to this problem.

b. To show that the basic methods and principles of automation of the national economy management, put forward 20-30 years ago, still keep their importance today. 
c. To present, at least partially, a description of the last stages of activity in the implementation of computers and automated management systems in our country and thus contribute to a more critical attitude to the plans and declarations that are put forward nowadays.

It is obvious that the materials presented do not include all the works and publications about this problem for a given period. Only my own works are presented because they describe, in my opinion, the general character of the work and efforts in this direction $[\ldots]$.

Appendices:

1. Report "Analysis of the automation of the national economy of the USSR for 30 years", 4 pages.

2. Copy of the letter of Anatoly Kitov to Nikita Khrushchev from January 7, 1959,4 pages.

3. Review of reports and articles of A. Kitov on automation of the national economy, 1955-1981, 9 pages.

Head of Computing Technology Department of Moscow Institute of National Economy named after G. V. Plekhanov, Doctor of technical sciences, Professor $<$ Signature $>$ A. I. Kitov.

Member of CPSU from 1944, party card № 06137014

9.10 .85

\section{Appendix}

\section{RESOLUTION}

of the scientific conference

on the theme "Role of the human factor and modern computers in the improvement of enterprise management", held jointly by the Moscow Institute of National Economy named after G.V. Plekhanov and the Volga Region House of Scientific and Technical Propaganda (Penza, 30-31 October 1989)

1. In the contemporary situation of the pre-crisis state of the economy one of the main ways to improve the management of enterprises, branches and the national economy as a whole according to perestroika aims is a wide application of automated accounting, planning and management systems based on modern computers. However, today an appropriate attention is not given to this very important problem $<\ldots>$

2. Now there is an extremely difficult situation in the field of computer engineering and informatics in our country with the organization of mass production of modern computers, their application and introducing of mass standard ASU as well.

Computer industry, on which for many years has been invested heavily [...], is unable to achieve the modern level of production. It is time to bring foreign companies in the business and establish joint ventures for the production of computers [...], purchases of computers and software abroad should be expanded as well. [...]

3. [...] It is necessary to tighten control over the real use of the purchased computers and software and provide concrete economic effects of their application.

4. The country has established a great number of organizations, parasitizing on computer science and computer engineering. First of all, this should be noted for the State Committee for Computer Science and Informatics, [...] the Institute for System Researches, Department of Informatics and Computer Engineering of USSR 
Academy of Sciences and various other institutions. It would be useful for the national economy and for the cause itself to liquidate them in the shortest time. Instead, an association of scientific and industrial enterprises should be established for the production and introduction of computers in the national economy.

5. Various automated management sub-systems are developed and introduced in the enterprises and their development is still continuing. It is necessary to analyze the existing projects, choose the best and make them standard for each branch of the industry. This would save a lot of money and resources. [...]

6 . It is necessary as soon as possible to organize the work on the development of unified schemes of management automation and information processing in the various types of enterprises [...]

7. The State Research and Production Association of Computer Engineering and Informatics (it seems that A. Kitov means here the above mentioned State Committee for Computer Science and Informatics, ndr) must organize the State network of information computer centers [...] carrying out a survey of enterprises, support and maintenance of typical automated systems of information processing and management.

8. The basic principle of production (purchase) of computers in our country should be their application according to the unified state plan in specific management automated and information processing systems with a predetermined economic effect and period of realization [...]

Chairman of the Conference

Doctor of technical sciences

Professor

A. I. Kitov

Head of the Computing Technology and Programming Department of the Moscow Institute of National Economy named after G.V. Plekhanov

\section{References}

1. Dolgov, V.A., Shilov, V.V.: The Icebreaker. Some Pages from Biography of Anatoly Ivanovich Kitov (Ледокол. Страницы биографии Анатолия Ивановича Китов). Novye technologii, Moscow (2009)

2. Shilov, V.V.: Anatoly Ivanovich Kitov's Biography: Stages of His Life and Scientific Work (Страницы жизни и научной деятельности Анатолия Ивановича Китова). Scientific Works of the Free Economic Society of Russia (Труды Вольного экономического общества России), vol. 143, 14-28 (2010)

3. Kitov, V.A., Shilov, V.V.: Anatoly Kitov - Pioneer of Russian Informatics. In: Tatnall, A. (Ed.) History of computing. IFIP AICT, vol. 325, pp. 80-88. Springer, Heidelberg (2010)

4. Ogandzhanyan, S.B., Shilov, V.V.: Anatoly Ivanovich Kitov's Contribution in Formation and Development of the Russian and World Informatics (Вклад Анатолия Ивановича Китова в становление и развитие отечественной и мировой информатики). Scientific Works of the Free Economic Society of Russia (Труды Вольного экономического общества России), vol. 164, 39-47 (2011)

5. Kitov, V.A., Shilov, V.V.: Anatoly Kitov: Technology vs. Ideology. The story about first project of nationwide computer network. In: The Second Region 8 IEEE Conference on the History of Telecommunications, pp. 1-3. IEEE (2010)

6. Kutejnikov, A.V., Shilov, V.V.: Automated Management System for the Soviet Union: A 1959 Letter from A. I. Kitov to N. S. Khrushchev (АСУ для СССР: письмо А.И. Китова Н.С. 
Хрущеву, 1959 г.). Studies in the History of Science and Technology (Вопросы истории естествознания и техники), 3, 45-52 (2011)

7. Kutejnikov, A.V., Shilov, V.V.: The Last attempt to revive the Project of the National System of Automatic Control of the Economy (OGAS): A.I. Kitov's 1985 Letter to M. S. Gorbachev (Последняя попытка реанимировать проект Общегосударственной автоматизированной системы управления советской экономикой ОГАС). Письмо А. И. Китова М.С. Горбачёву, 1985 г.). Studies in the History of Science and Technology (Вопросы истории естествознания и техники), 2, 100-109 (2013)

8. Meshcheryakov, G.A.: The Interrupted Flight (Прерванный полёт), http://www.computermuseum.ru/galglory/ kitov_7.htm

9. Kitov, V.A., Shilov, V.V., Silantiev, S.A.: Anatoly Kitov and ALGEM algorithmic language. In: AISB/IACAP World Congress. International Symposium on History and Philosophy of Programming, pp. 1-3. Birmingham (2012)

10. Kitov, V.A.: Computer "Strela" for Creating the USSR Defense Shield (ЭВМ "Стрела" при создании оборонного щита СCCP). In: SORUCOM-2014 (Труды SORUCOM-2014), pp. 171-172. Kazan (2014)

11. Kitov, V.A., Prikhod'ko, A.Ya.: The 60th Anniversary of Computing Center Number 1 of the USSR Ministry of Defense. In: Tomilin, A.N. (Ed.) SoRuCom-2014, pp. 45-47. IEEE Computer Society (2014)

12. Dolgov, V.A.: Kitov Anatoly Ivanovich - Pioneer of cybernetics, informatics, and automation control systems (Китов Анатолий Иванович - пионер кибернетики, информатики и автоматизированных систем управления). Plekhanov Russian Academy of Economics, Moscow $(2009,2010)$

13. Tuchkov, V.Ya.: Pioneer of digital continent (Первопроходец цифрового материка). Plekhanov Russian Academy of Economics, Moscow (2014)

14. Neskoromny, V.: The man who brought Cybernetics from the secret library (Человек, который вынес кибернетику из секретной библиотеки). Computerra (Компьютерра), 43, 44-45 (1996)

15. Kutejnikov, A.V.: At the beginning of a computer era: The prehistory of the Project of the Nationwide automated management system of economy in USSR OGAS (Ha заре компьютерной эры: предыстория разработки проекта Общегосударственной автоматизированной системы управления народным хозяйством СССР ОГАС). History of Science and Engineering (История науки и техники), 2, 39-54 (2010)

16. Shilov, V.V.: Anatoly Ivanovich Kitov: the Autumn of the Patriarch (Анатолий Иванович Китов: осень патриарха). Vestnik of the Plekhanov Russian University of Economics (Вестник Российского экономического университета им. Г. В. Плеханова), 4 (82), 122-127 (2015)

17. Gerovitch, Slava: InterNyet: why the Soviet Union did not build a nationwide computer network. History and Technology. 24 (4), 335-350 (2008)

18. Graham, Loren R. Science, Philosophy, and Human Behavior in the Soviet Union. Columbia University Press, New York Guildford, Surrey (1987)

19. Gerovitch, Slava: From Newspeak to Cyberspeak. A History of Soviet Cybernetics. The MIT Press, Cambridge, MA (2002) 